\title{
High Resolution Melt Analysis (HRM) and its Strategic Applications Especially in Molecular Genetics
}

\author{
Noori-Daloii M.R.* PhD, Faraji K. ${ }^{1}$ BSc
}

*Medical Genetics Department, Medicine Faculty, Tehran University of Medical Sciences, Tehran, Iran
1Medical Genetics Department, Medicine Faculty, Tehran University of Medical Sciences, Tehran, Iran

\begin{abstract}
Introduction: In wide and developing worlds of cellular and particularly molecular sciences, the most important issue that leads to paying more attention to and use a technique, is its critical features; high sensivity, specificity, velocity and also being available and cheap. High Resolution Melting (HRM), may be one of these techniques. Its usage is growing among others significantly in investigations, for its special advantages. HRM is based on the pattern and characteristic of DNA when melting. DNA melting temperature $(\mathrm{Tm})$, is the temperature that $50 \%$ of DNA molecules have become single stranded and 50\% are double stranded. The pattern of getting single stranded is specific and unique for every DNA strand; and differences are shown as a graph called "melting curve". These are effective on DNA Tm: the value of bases $\mathrm{G}$ and $\mathrm{C}$ in both DNA strands (CG\%), the length of fragment, the static effects of bases on each strand and the hetrozygocity. In fact, the differences among melting curves results in recognition the special fragment. The way of being single stranded can be followed by fleurcence colors which attached to double stranded DNAs.

Conclusion: High-resolution melting is powerful, fast, comprehensive and useful technique for using in molecular laboratory that can be considered as simple and fast approach for genotyping, mutation detection, matching sequence and methylation study.
\end{abstract}

\section{Keywords}

High Resolution Melting [Not in MeSH];

Molecular Biology [http://www.ncbi.nlm.nih.gov/mesh/68008967];

Molecular Diagnostic Techniques [http://www.ncbi.nlm.nih.gov/mesh/68025202]

\footnotetext{
* Corresponding Author

Tel: +98218853005

Fax: +98218853005

Address: Medical Genetics Department, Medicine Faculty, Tehran University of Medical sciences, Poursian Street, Keshavarz Boulevard, Tehran, Iran

nooridaloii@sina.tums.ac.ir

Received: January 14, 2015 
استفاده قرار كيرد، آن است كه فن مورد نظر از دقت، سرعت و

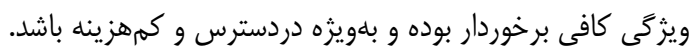

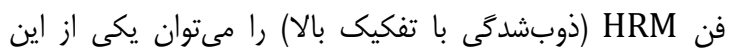

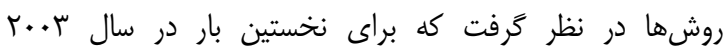

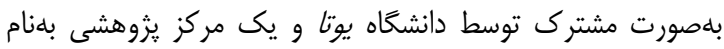

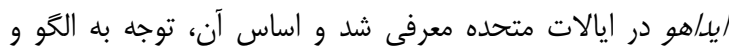

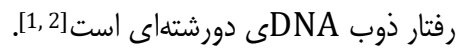

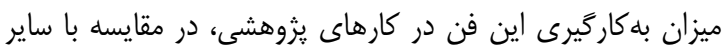

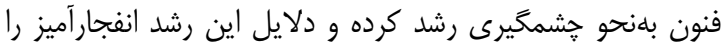

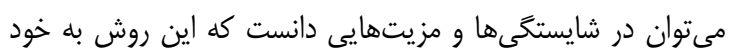

$$
\text { اختصاص داده است (شكل (). }
$$

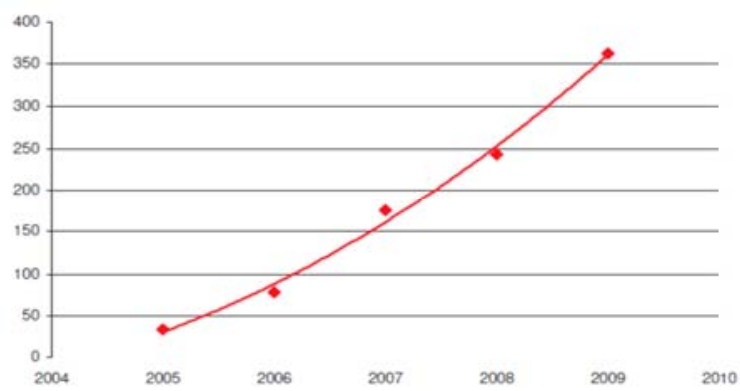

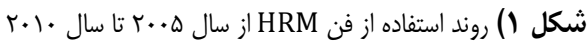

شمارى از مزيتهاى اين فن بهاشرح زير است: دقت و حساسيت

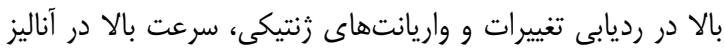

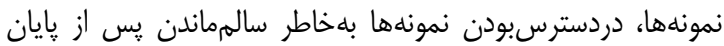

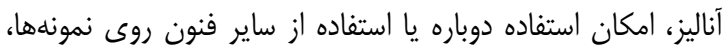

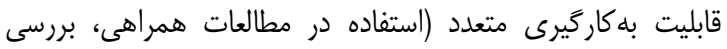

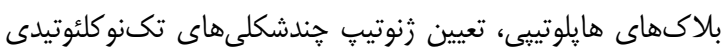

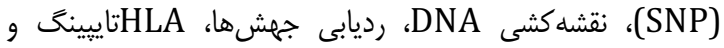

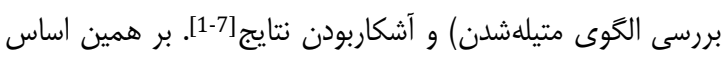

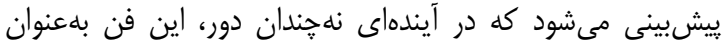

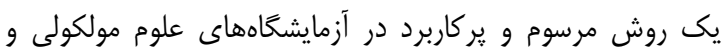
بلويزه رزنتيك مولكولى مورد استفاده قرار كيرد.

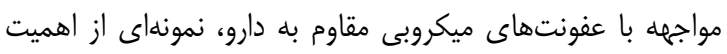

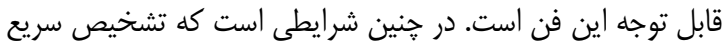

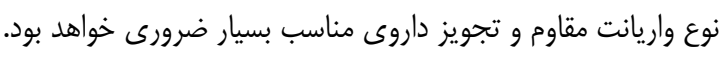

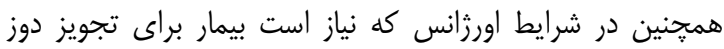

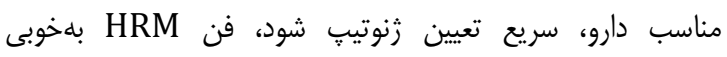
جوابكوى آنها است [8, [8,.

\section{ويزَّىهاى اصلى فن HRM}

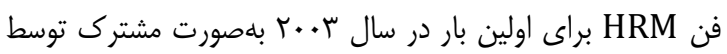
دانشخاه يوتا و يك مركز يروهشى بلهنام /يداهو در ايالات متحدها معرفى شد و دارى سه ويزّى اصلى بهشرح زير است:

\section{فن ذوب DNA با تفكيك بالا و كاربردهاى راهبردى آن بلويزه در زنتيك مولكولى}

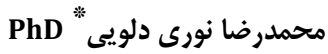

كروهو زُنتيك يزشكى، دانشكده يزشكى، دانشكاه علوم يزشكى تهران، تهران،

ايران

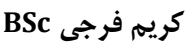

كروه زرنتيك يزشكى، دانشكده يزشكى، دانشاء علوم يزشكى تهران، تهران،

ايران

جكيده

مقدمه: در دنياى كسترده و در حال رشد علوم سلولى و بهويثه مولكولى،

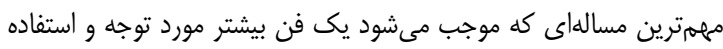

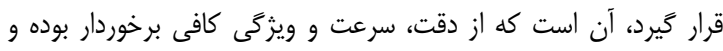

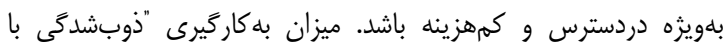

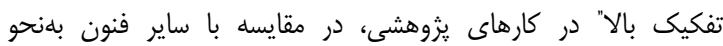

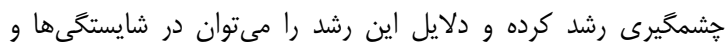

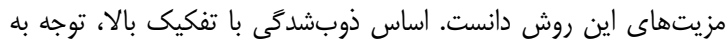

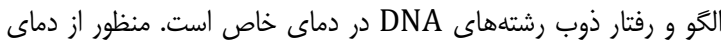

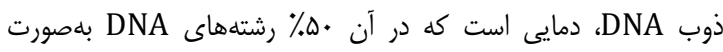

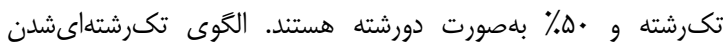

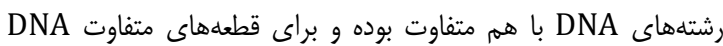

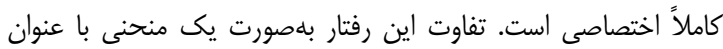

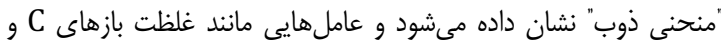

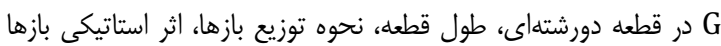

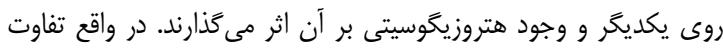

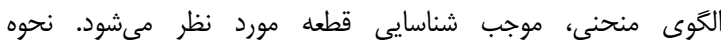

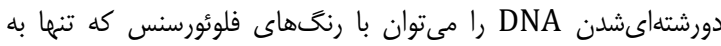
Dئى دورشتهاى متصل مىشوند، دنبال نمود.

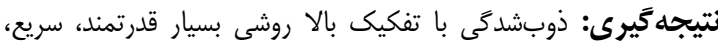

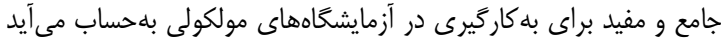

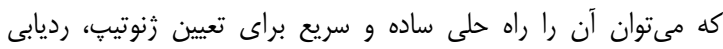
جهش، تطابق توالى و بررسى الكَّى متيلاسيون دانست

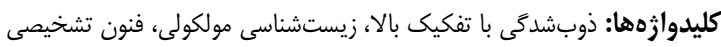

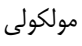

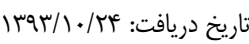

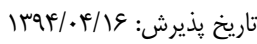
nooridaloii@sina.tums.ac.ir :نويسنده

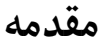

در دنياى گَترده و در حال رشد علوم سلولى و بلهويزه مولكولى، مهنه

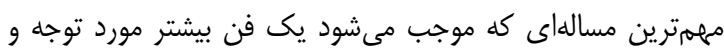

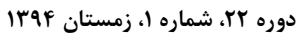

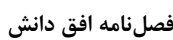




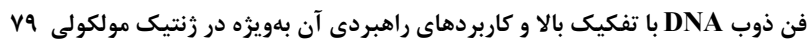

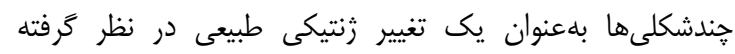

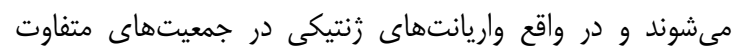

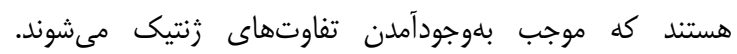

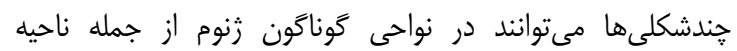

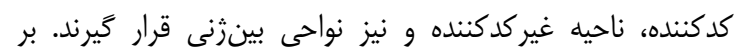

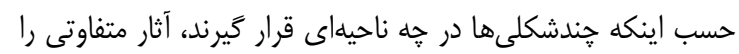

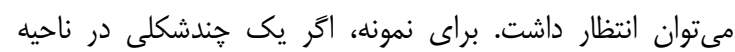

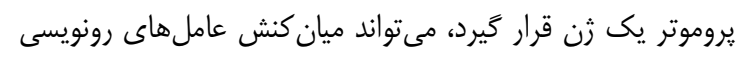

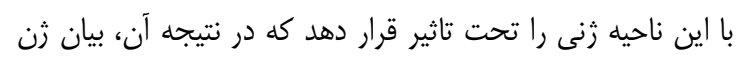

$$
\text { نيز دست خوش تغيير قرار مى كيرد. }
$$

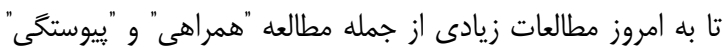

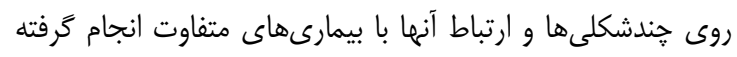

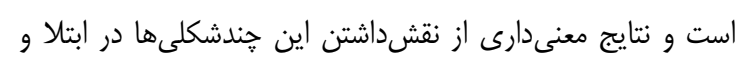

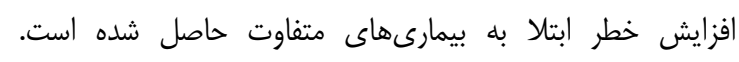

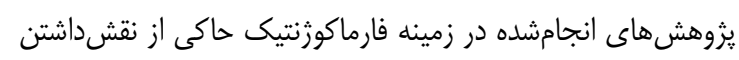

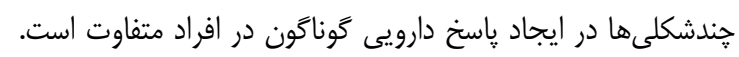

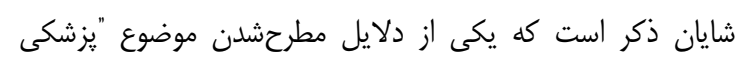

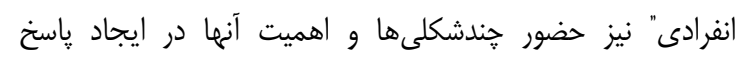

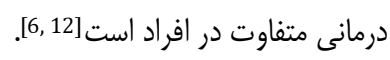

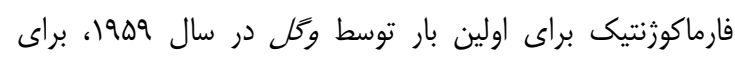

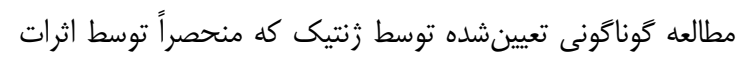

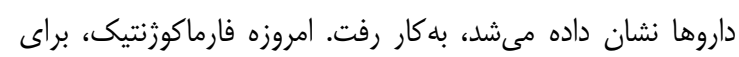

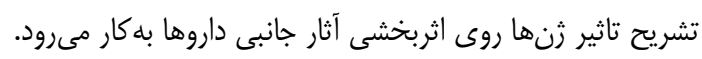

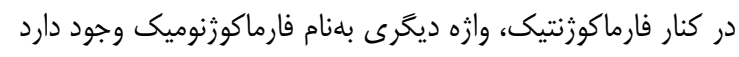

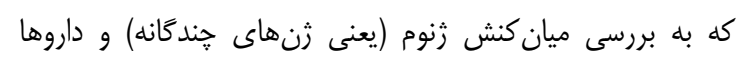

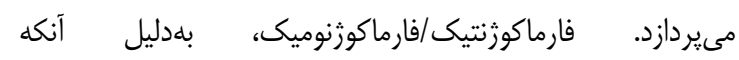

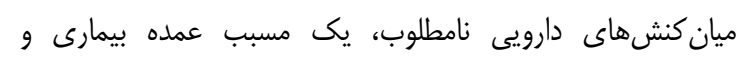

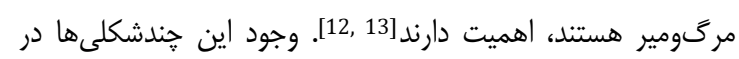

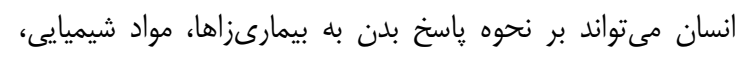

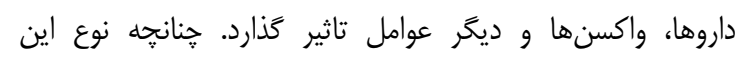

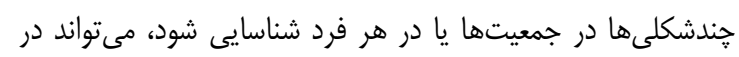

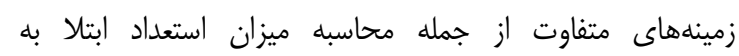

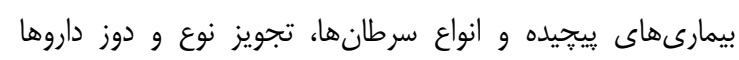

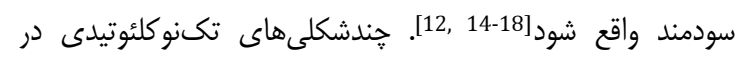
جهار گروه ردهبندى مى شوند (جدول ().

جدول () طبقهبندى انواع ردهاى SNP

\begin{tabular}{|c|c|c|c|}
\hline SNP رده & تغيير بازى & تغيير معمول Tm & فراوانى در انسان \\
\hline يك & $\mathrm{G} / \mathrm{A}, \mathrm{C} / \mathrm{T}$ & & $\%$ \\
\hline دو & $\mathrm{C} / \mathrm{A}, \mathrm{G} / \mathrm{T}$ & بيشتر از ه/• درجه & $\%$. \\
\hline سه & $\mathrm{C} / \mathrm{G}$ & & $\% 9$ \\
\hline جهار & $\mathrm{A} / \mathrm{T}$ & كمتر از r/. درجه & $\% \vee$ \\
\hline
\end{tabular}

1- استفاده از رنخ فلوئورسنس با غلظت نسبتاً بالا.

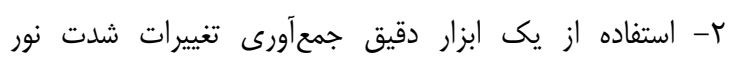
فلوئورسنس بر حسب تغييرات دما.

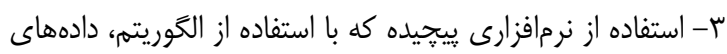

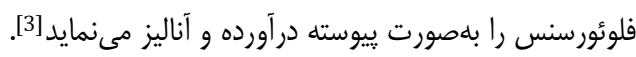

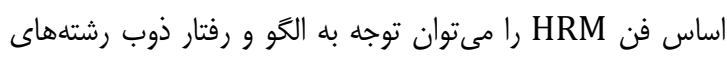

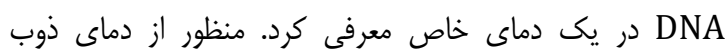

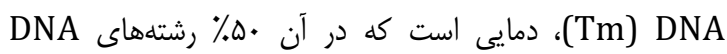

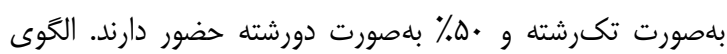

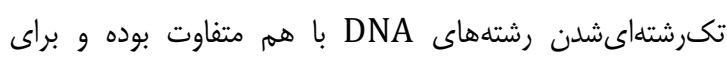

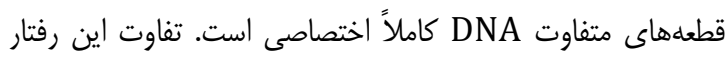

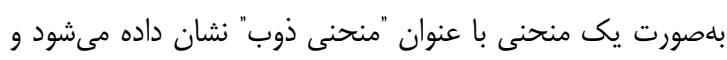

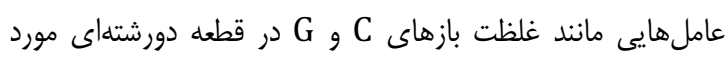

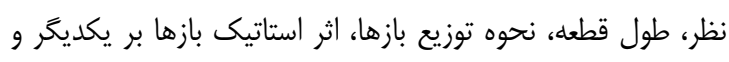

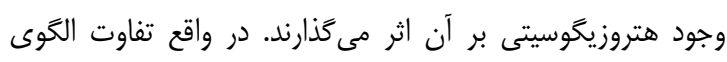

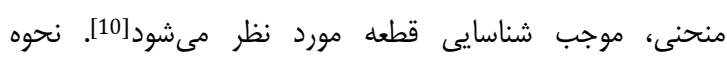

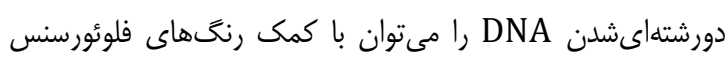

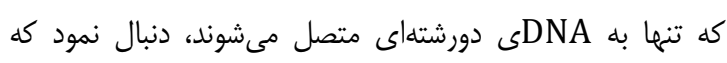
شكل r نشاندهنده اين روند است.

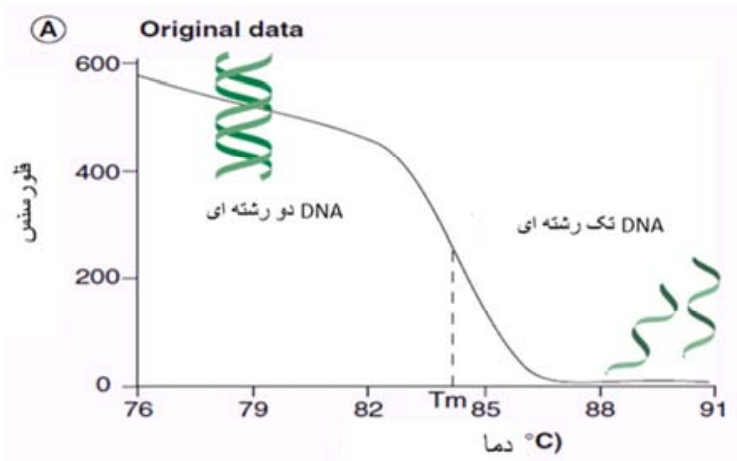

شكل r) روند تكرشتهاى شدن DNA دورشتهاى حين افزايش دما. همزمان با فمان

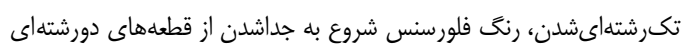
نموده و شدت آن كم مى شودد.

هنخامى كه DNA شروع به تكرشتهاىشدن مىنمايد، اين رنخها

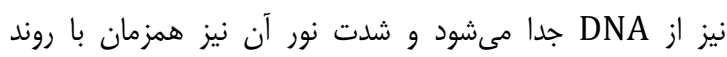

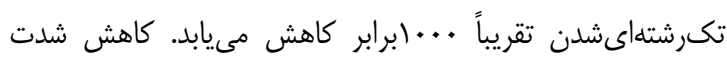

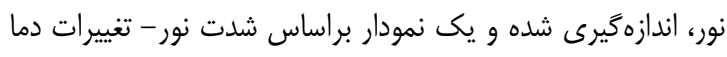

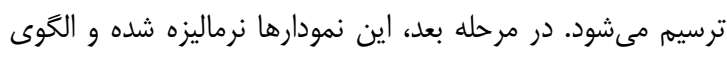

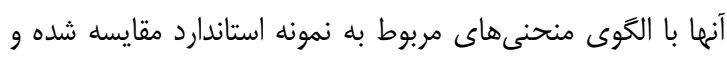

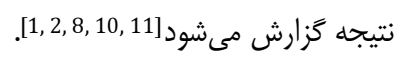

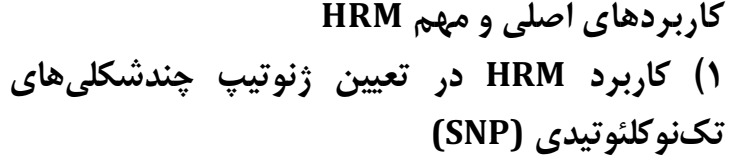


منحنى مرجع متفاوت خواهد بود (شكل عا). اخيراً از روش HRM براى رديابى جهشهاى نقطه در زنهايى همجون BRAF، KRAS و PIK3CA قابل قبولى برخوردار بوده است [23-27].

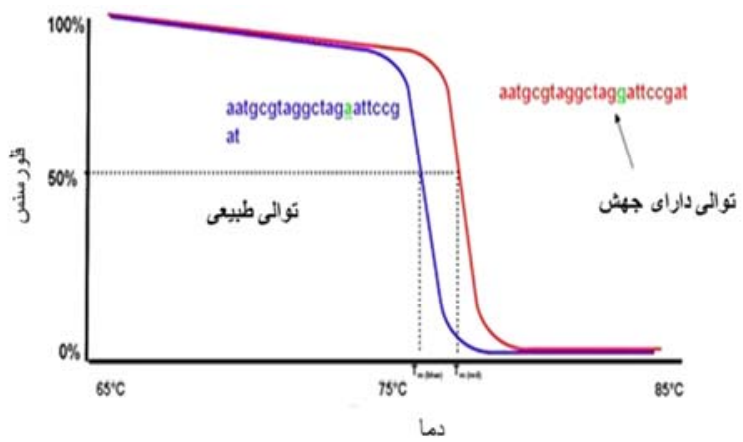

شكل ع) تغيير الخوى ذوب رشته سالم و رشته دارنده جهش. وقوع جهش در

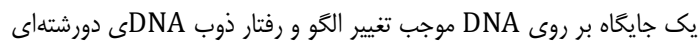

مىشود.

در فن HRM بهدليل سالمماندن نمونهها پِ از پِايان آناليز، امكان

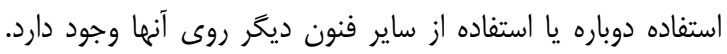
براى نمونه، جنانجه نتايج بهدستآمده در

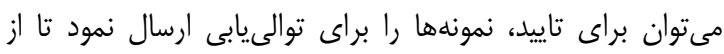
درستى نتايج HRM مطمئن شد [1-31-23].

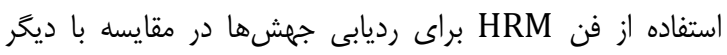

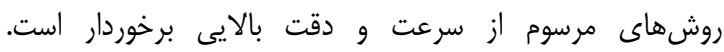

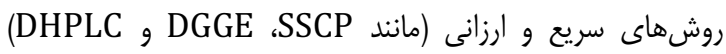

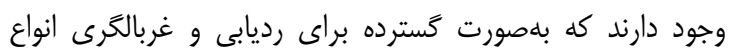

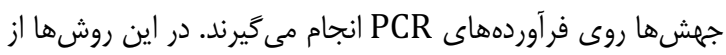

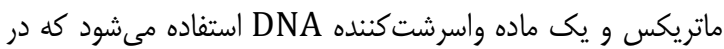

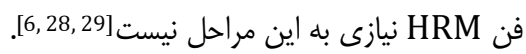

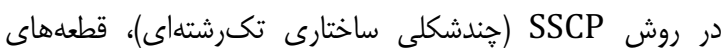

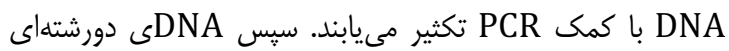

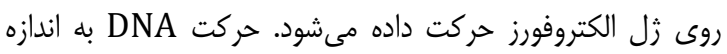

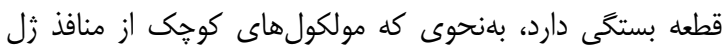
بهآسانى عبور مى كنند. در الكتروفورز SSCP ابتدا از يك مارك ماده

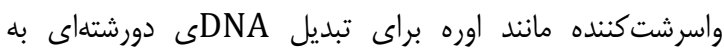

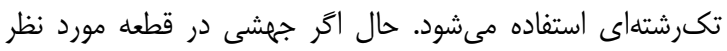

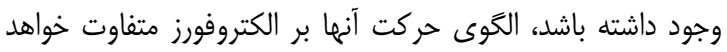

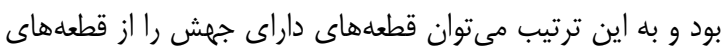

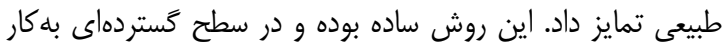

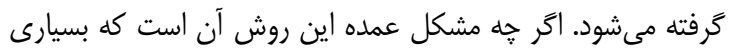
از جهشها شناسايى نمىشوند، زيرا بسيارى از آنها تاثيرى بر بر رشته إنه

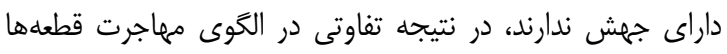
روى زل مشاهده نمى شود. بر همين اساس سطح رداسئ رديابى و

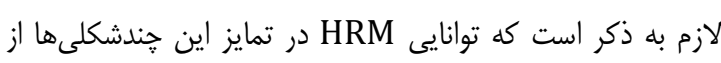

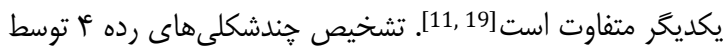

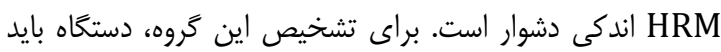

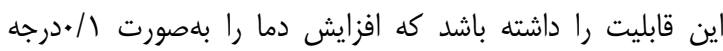

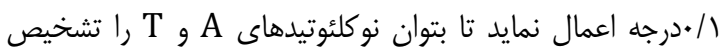

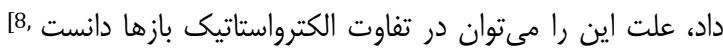

.20]

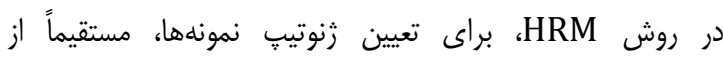

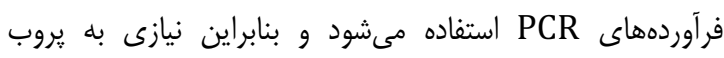

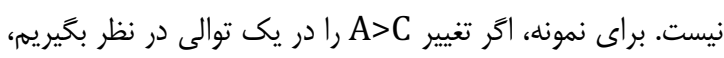

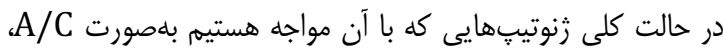

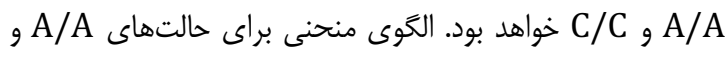

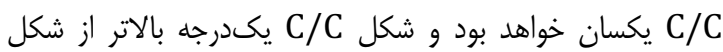

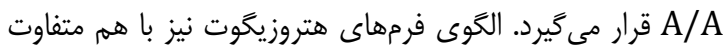

خواهد بود (شكل r).

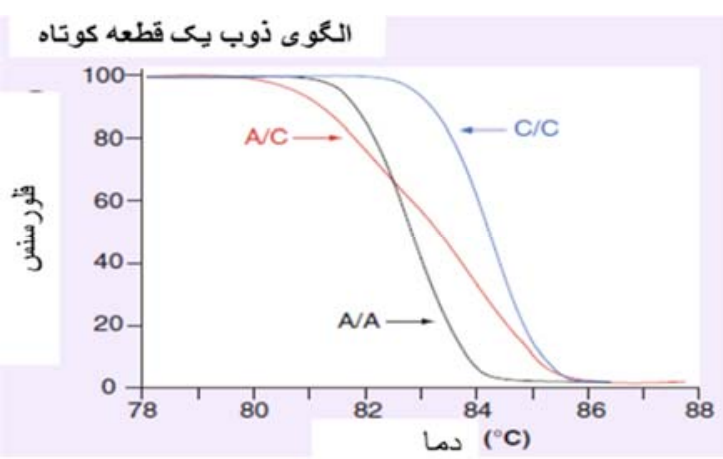

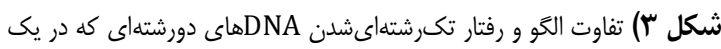

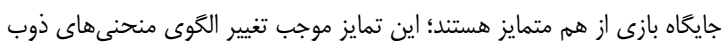
مى شود.

حال اگر بازه تغييرات دمايى را وسيعتر انتخاب نماييم (براى نمونه

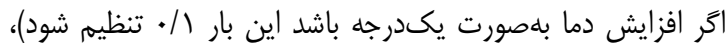

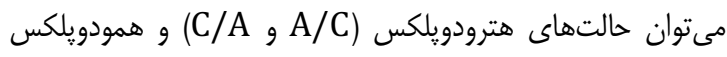
(C/C و A/A)

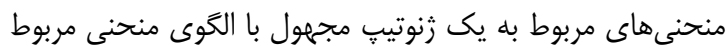

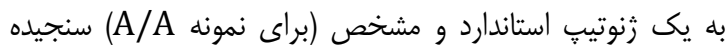

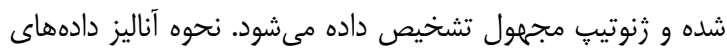

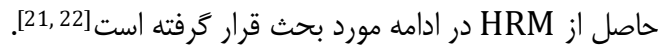

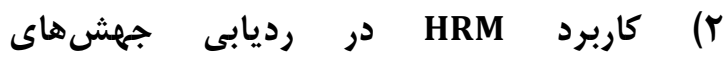
تكىنو كلئوتيدى

در روش HRM، براى تعيين و شناسايى جهش، همانند تعيين

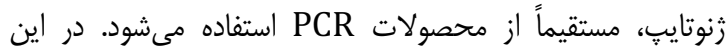

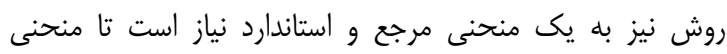

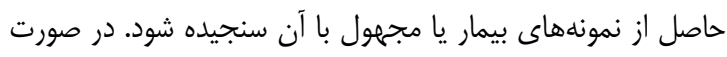

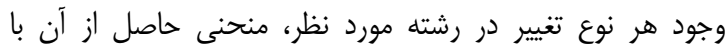

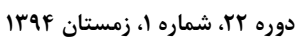
فصلنامه افق دانش 


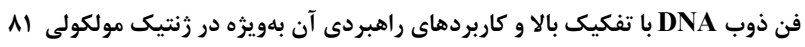

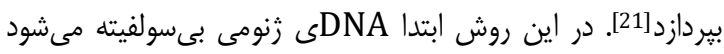

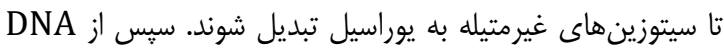
استفاده مىشود. شايان تاكيد است كه طراحى ڤرايمر در فن -

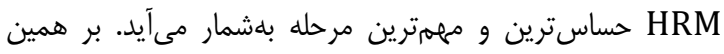
اساس ييشنهاد شده است كه براى طراحى زيرايمر از نرمافزار Methyl Primer Express® V1.0

طراحى يرايمر متيله برنامهريزى شده است، استفاده شود[11].

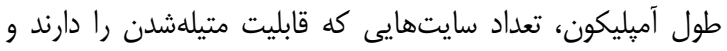
قرارگيرى CpGها در درون توالى يرايمر، از جمله نكاتى هستند كه

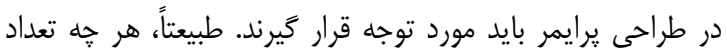
سايتهايى كه قابليت متيلهشدن را دارند در قطعه مورد نظر بيشتر باشد، ميزان اختلاف Tm آن با نمونههاى مرجع غيرمتيله و كاملاً

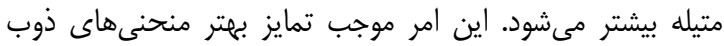

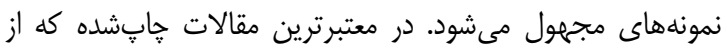

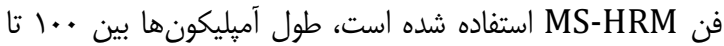

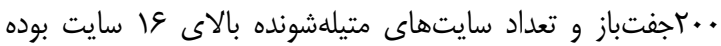

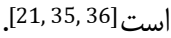

هنگامى كه حداكثر حساسيت تشخيص متيلهشدن مورد نياز است مىتوان يرايمرها را طورى طراحى كرد كه دربردارنده گروههاى

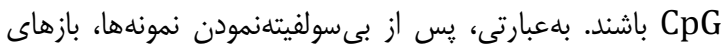

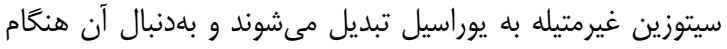

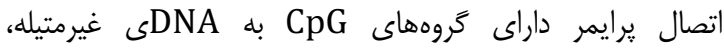
"جفتشدن ناجور بازها" وجود خواهد داشت كه همين امر ميزان

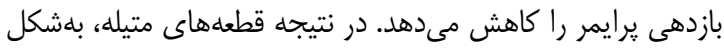
كامل به يرايمر اتصال يافته و بلهسهولت تكثير خواهند شد. همجنين

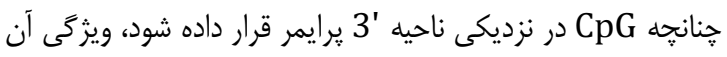
براى اتصال به DNADى متيله افزايش خواهد يافت [21,35].

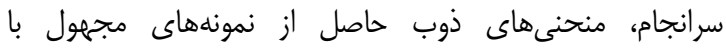
منحنى هاى ذوب استاندارد (منحنى ذوب مربوط بهاب به نمونههاى مرجع كه داراى درصد متفاوت و مشخص متيل هستند) مقايسه شده و و سيس نتيجه كَارش مى شود.

\section{نحوه انتخاب طول قطعه و اصول طراحى ير ايمر در فن}

HRM

براساس منابع علمى معتبر و جديد در انتخاب طول قطعه مورد نظر

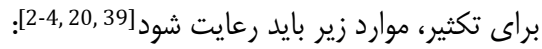

الف) طول قطعه بين • V تا + +. نو كلئوتيد باشدي

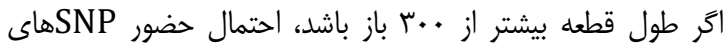

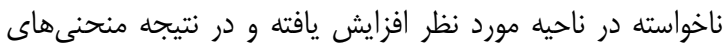
حاصل يِجيده مىشود. همجنين، با افزايش طول قطعه احتمال

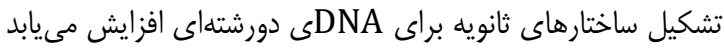

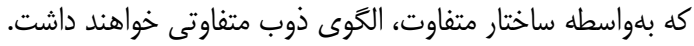

تشخيص اين فن براى جهشها، در حدود V\% گزارش شده

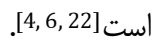

روش DGGE (الكتروفورز روى زل با شيب واسرشتكننده) در مقايسه با فن SSCP با قدرت تشخيص بالاى هو٪٪، بهمراتب

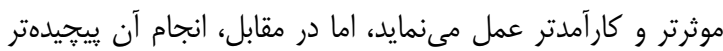

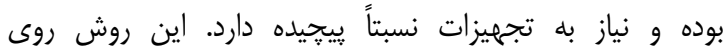

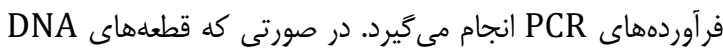
در يك نوكلئوتيد با هم متفاوت باشند، واسرشتشدن آنها در سطح

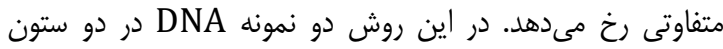

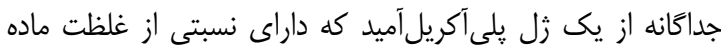

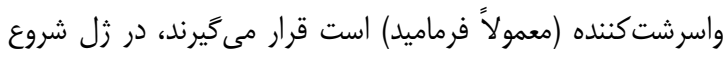
به حركت مى كنند و زمانى كه به نقطه مناسبى از غلظت مئ ماده واسرشتكننده مىرسند شروع به جداشدن مىنمايند. اين نقطه بهنوان يك نقطه ذوب عمل كرده و در اين حالت بلهصورت هشمگيرى از سرعت حركت قطعهها كمم مىشود و براى قطعههاى سالم و قطعههاى داراى جهش متفاوت است. به اين ترتيب قطعه داراى جهش رديابى مىشود [12]. روش DHPLC (كروماتوكرافى مايع DNA با كارآيى بالا)، بيشتر براى شناسايى هندشكلىهاى تكىنوكلئوتيدى استفاده شده و داراى قدرت تشخيص بالاى عף٪ است و روى فرآوردههاى PCR انجام

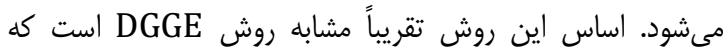

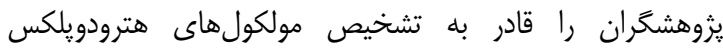
توليدشده در PCR مى كند [12]. فن HRM در مقايسه با روشهاى مورد اشاره در بالا، مزايايى

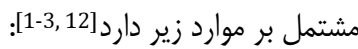
• الف) عدم نياز به ماتريكس.

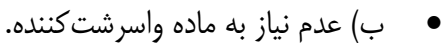

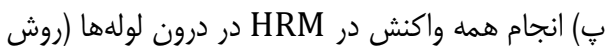
لوله دربسته) و عدم نياز به خارجسازى فرآوردههاى

.PCR ت) بهحداقلرسيدن احتمال ورود آلودگى به واكنش بهدليل عدم خروج فرآوردهها از لوله.

لازم به ذكر است كه ويثگى و حساسيت فن HRM تغييرات تكنوكلئوتيدى در فرآوردهاى PCR با طول · •. أجفتباز

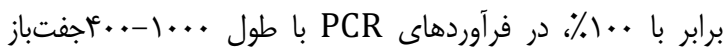

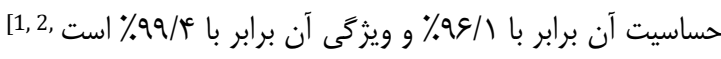
$26,30-34]$

\section{ץ) كاربرد HRM در بر رسى تطابق توالى}

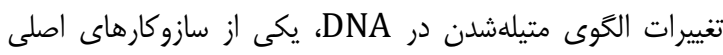
ايعزنتيكى براى كنترل بيان ثن است. فن HRM) MS-HRM

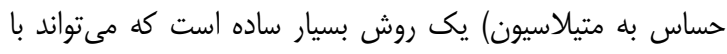
دقت و سرعت كافى به بررسى الخوى متيلهشدن در بله زنوم 
در بيى انجام اين بخش مرحله جهارم با انتخاب كزينه Profile

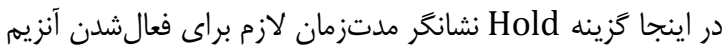

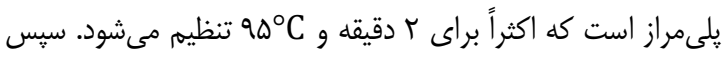

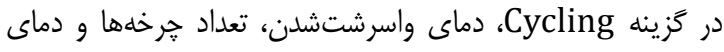
اتصال يرايمر تنظيم مى شود.

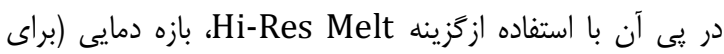

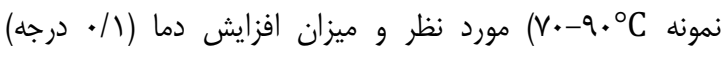

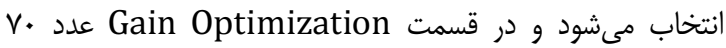
انتخاب مىشود؛ به اين معنى كه شدت نور فلون فئو فئورسنس از مقدار

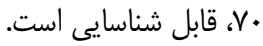
مرحله ينجم: بهنمايشدرآمدن اطلاعات واردشده براى كنترل

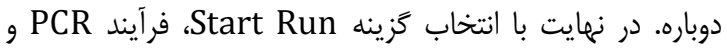

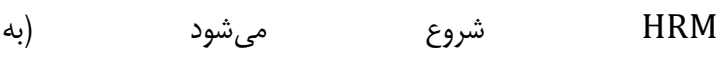
jcu.edu.au/cgc/HRMTA_design.pdf

آناليز HRM براى آناليز HRM در حالت كلى ه مرحله بهاشرح زير بايد طى شود:

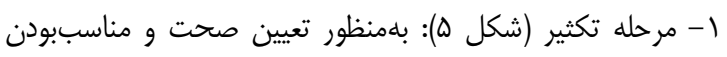

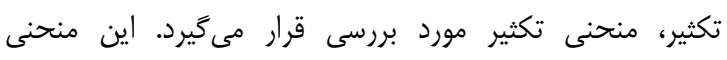

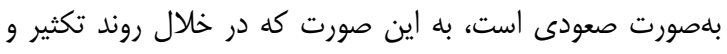

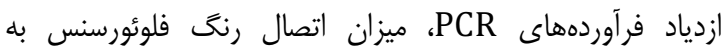

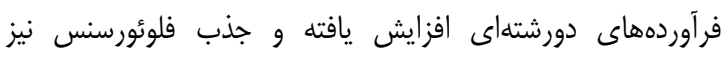

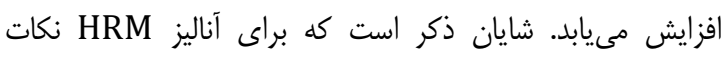

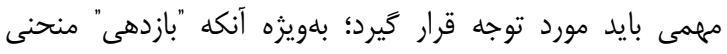

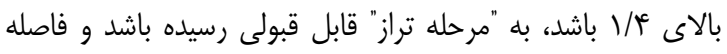

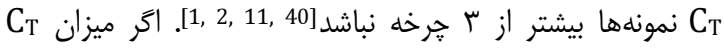

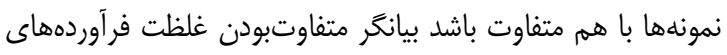

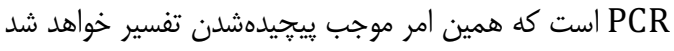

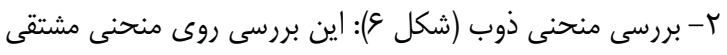

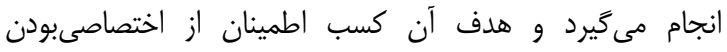

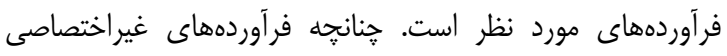

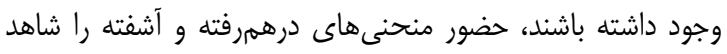

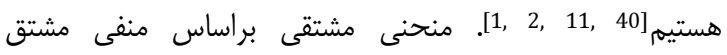
فلوئورسنس تقسيم بر مشتق دما (محور Y) به دما (محور X) رسم

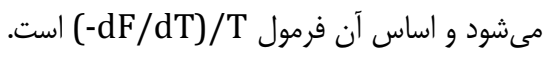

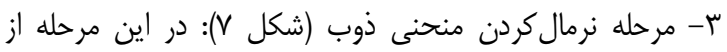

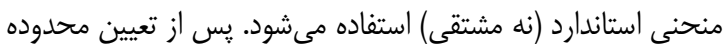

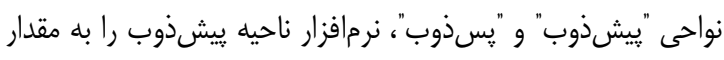

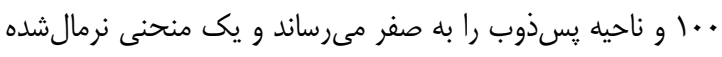

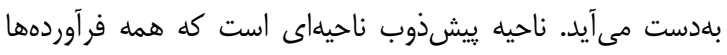

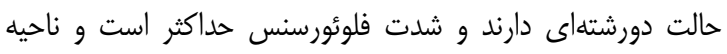

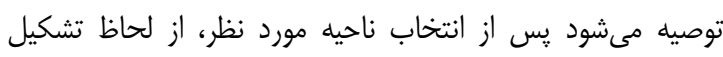

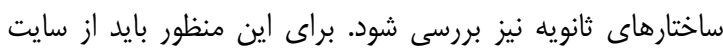

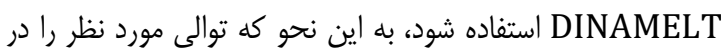

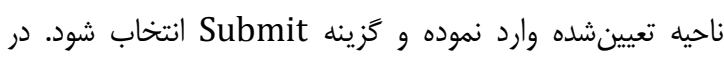
نهايت شكل ساختارهاى ثانويه بلهمراه ميزان نمايش داده مىشود. لازم به ذكر است كه ميزان قابل قبول ساختارهاى ثانويه تا ا - است.

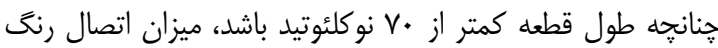

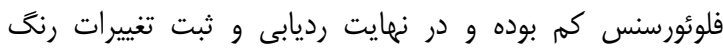

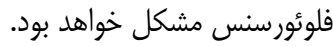
ب) در طراحى يرايمر بايد موارد زير در نظر ترائر شود [2-4, 20,39]:

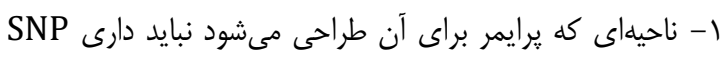

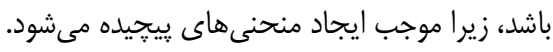

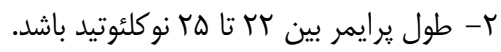

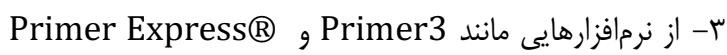
3.0 براى طراحى يرايمر استفاده شود.

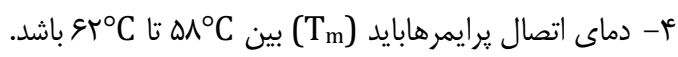

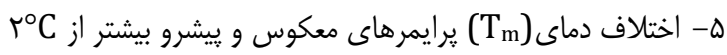
نباشد.

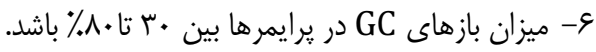
DG -V

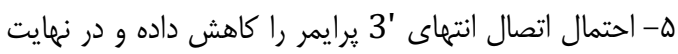

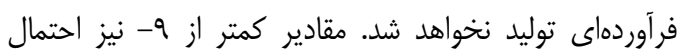

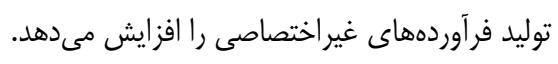

DG -^ تشكيل برايمر دايمر حداكثر تأ أب- باشد.

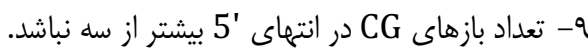
هG

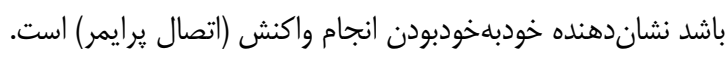

\section{HRM نحوه كار با نرمافزار}

مرحله اول: اجراى برنامه با انتخاب ززينه New Run و كزينش .High Resolution Melting

مرحله دوم: انتخاب نوع يليت با توجه به نوع دستكاه PCR.

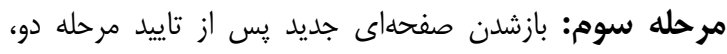

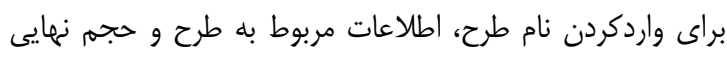
نمونه واكنش و كليك كردن كزينه

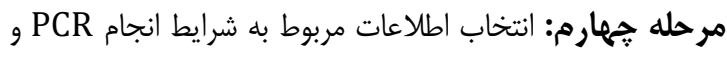

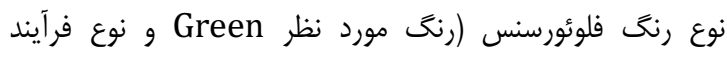
HRM 


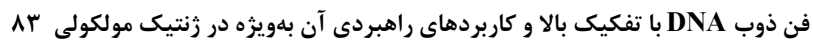

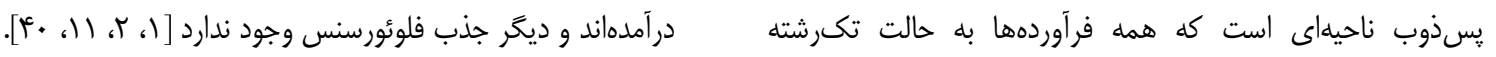
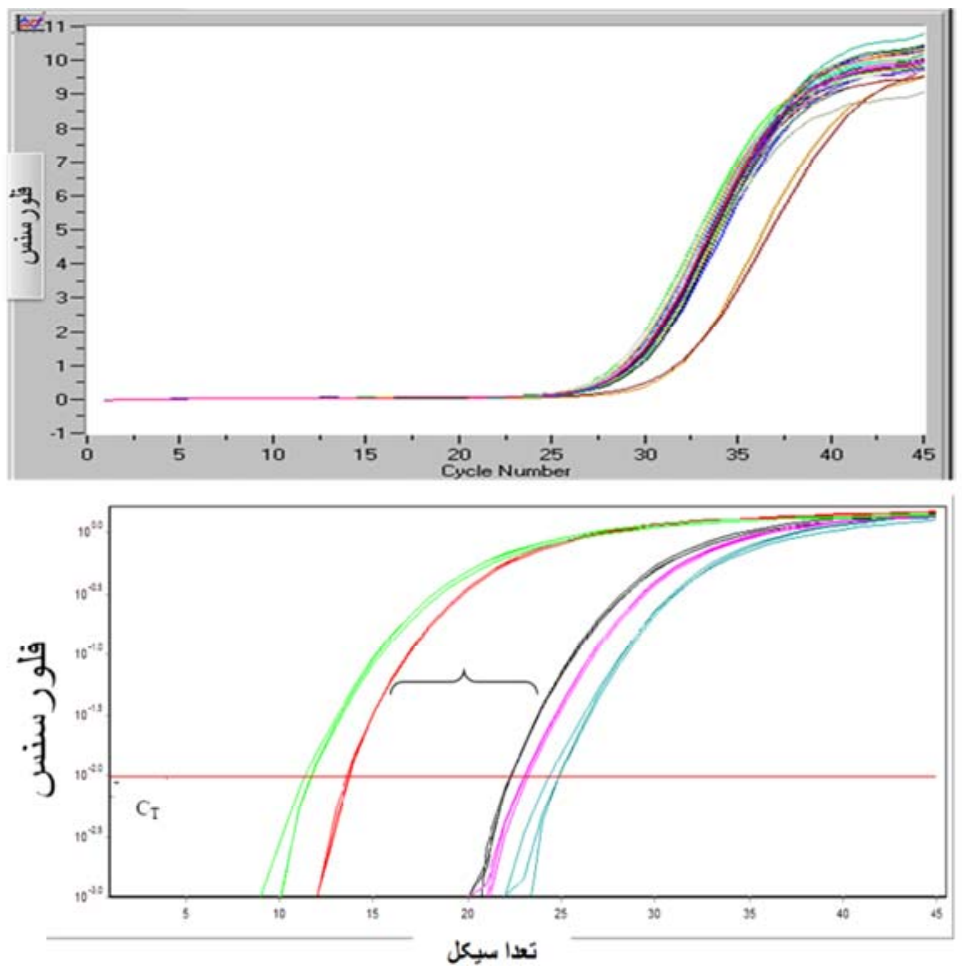

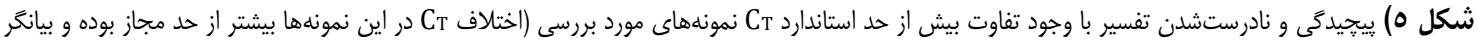
تفاوت غلظت فرآوردهها در نمونه است)

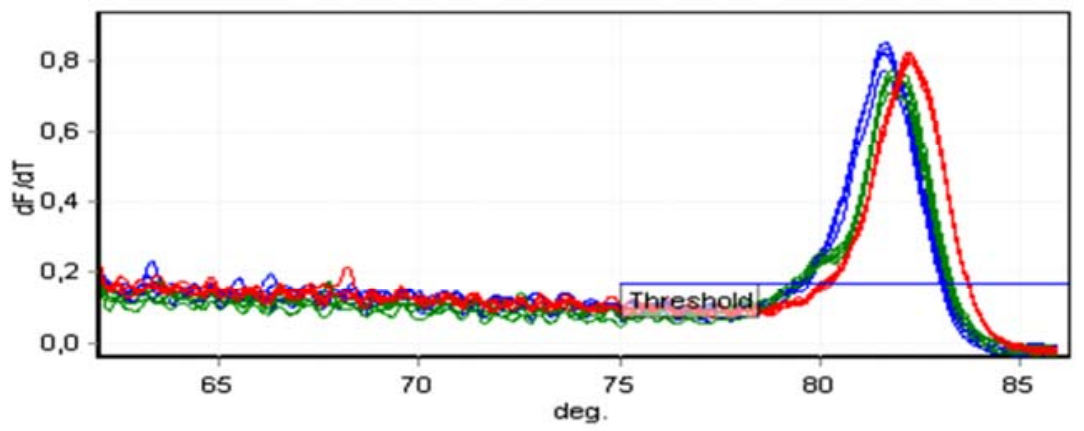

شكل 7) منحنى ذوب منحنى مشتقى بوده و بهمنظور بررسى اختصاصىبودن فرآوردههاى مورد نظر بهكار مىرود.

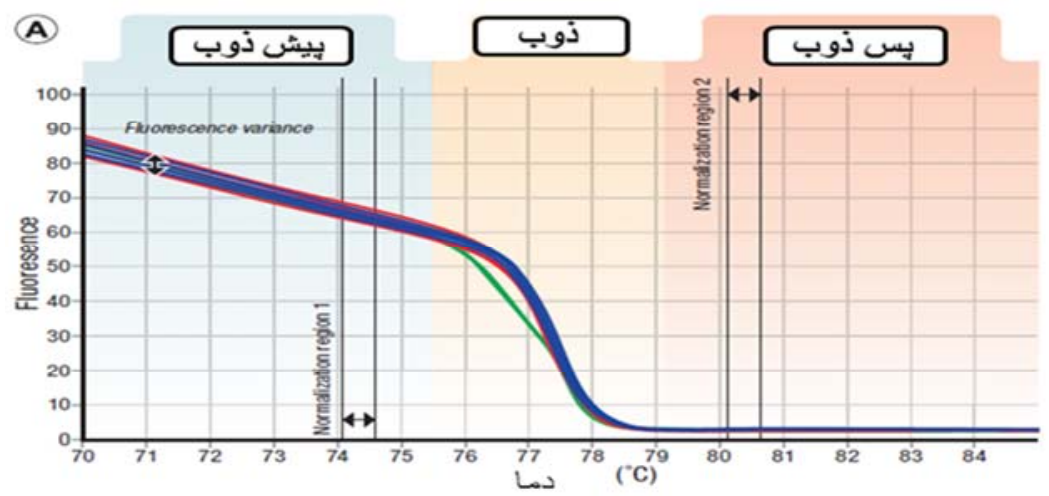

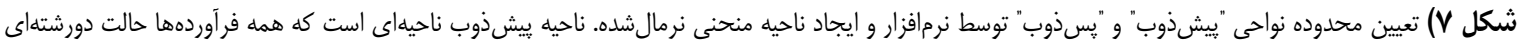

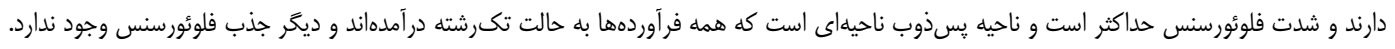




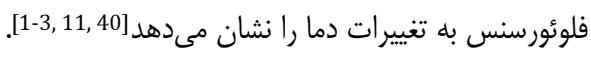

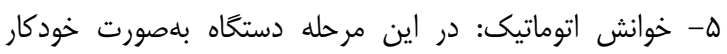

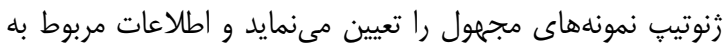

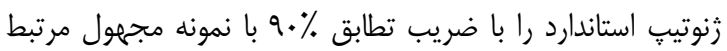

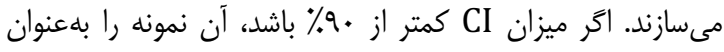

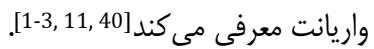

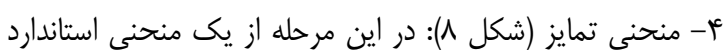

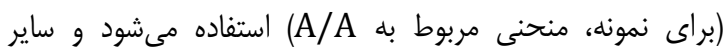

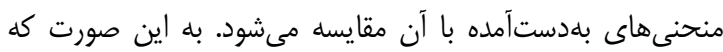

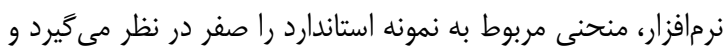

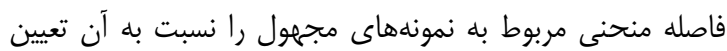

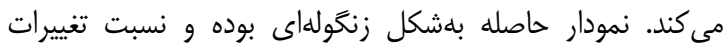

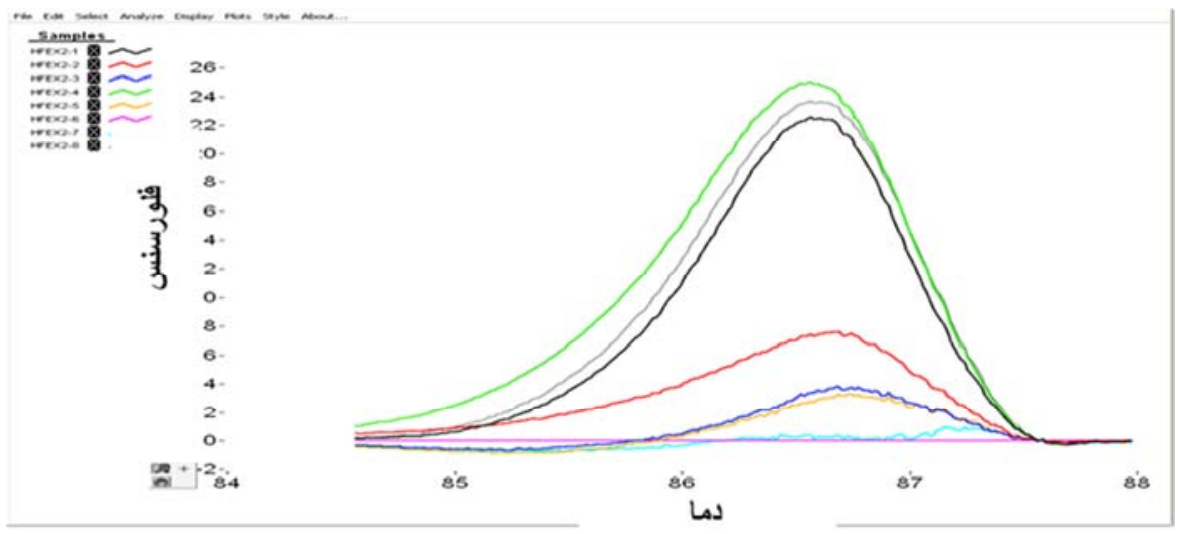

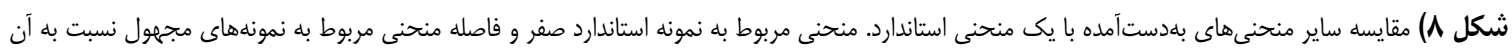

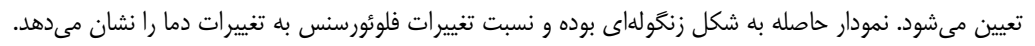

9 Light Cycler Roch ،Lightscanner 96/384 Rotor-Gene 6500 HRM

\section{نكات قابل اهميت و توجه خاص در استفاده از فن}

HRM

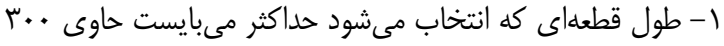

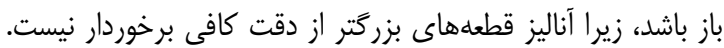

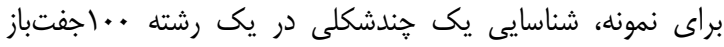

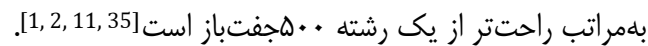
r- استفاده از فرآوردههاى خالص PCR.

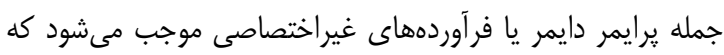

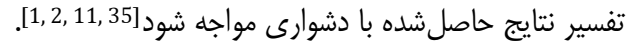

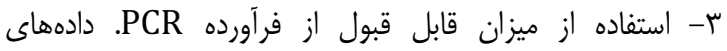

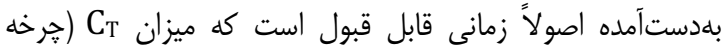

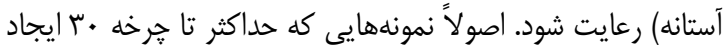
شدهاند براى آناليز مناسب هستند. فر آوردههاى بهدست آمآمده از خرخه سىام بهبعد بهخاطر فرآيندهاى "اثرات تخريب الكَ" و و "مقدار كم

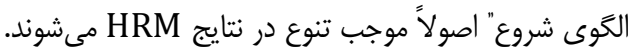

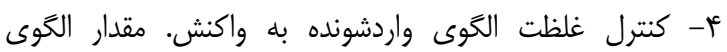

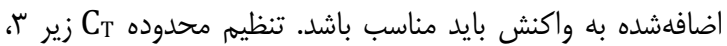

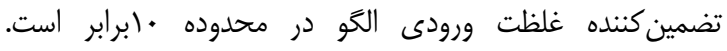
بلعبارتى، بايد اختلاف C نمونهها بيشتر از بّ هرخه نباشد.
دمتخاههای HRM

تا سال •la براى بررسى رفتار ذوب DNAى دورشتهاى از

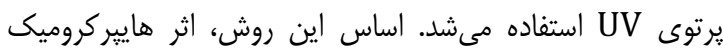

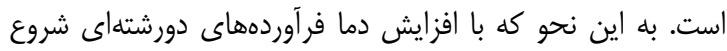
به بازشدن از هم نموده و بازهاى موجود در رشتهها بيشتر در درائر

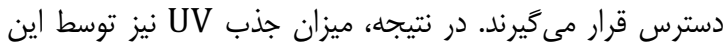

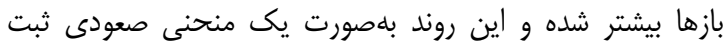

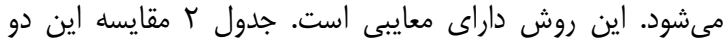

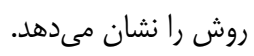

\begin{tabular}{|c|c|c|}
\hline UV & HRM & تفاوتها \\
\hline ميكروگرم/ & 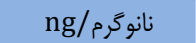 & مقدار DNA مورد نياز \\
\hline ساعت & دقيقه & زمان لازم براى ذوب \\
\hline 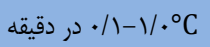 & 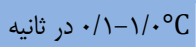 & سرعت \\
\hline
\end{tabular}

از سال 199 براى بررسى الكوى ذوب DNAى دورشتهاى،

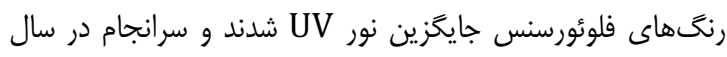

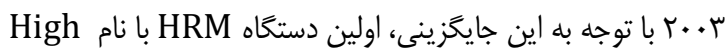
Resolution Melter-1 ميزان درخواست براى استفاده از اين روش، دستخاههاى آن از لحاظ

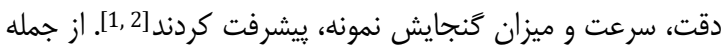

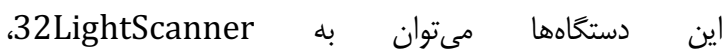




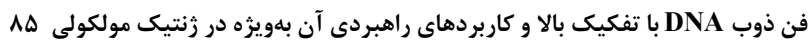

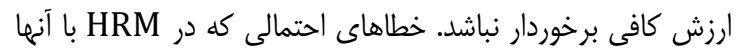

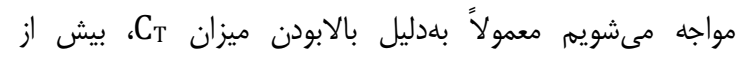

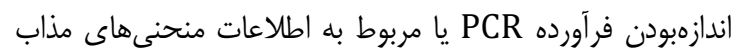

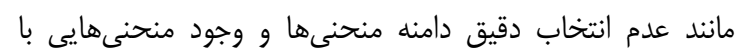
دامنه ذوب متعدد است.

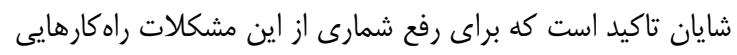

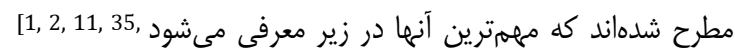

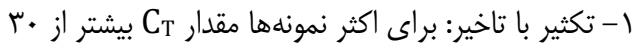

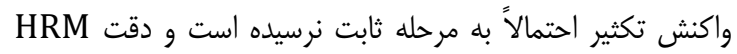

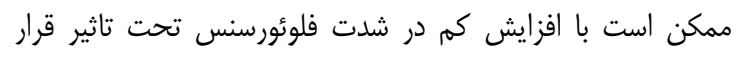

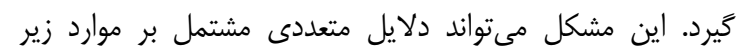
داشته باشد:

الف) بايينبودن كيفيت DNA كه راه حل آن تكرار استخراج DNA

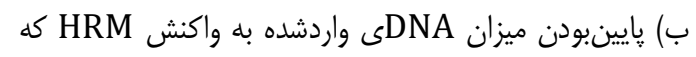

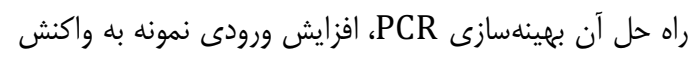
يا افزايش تعداد خرخه است.

r- تكثير با تاخير برخى از نمونها: براد است براى برخى از نمونهها مقدار

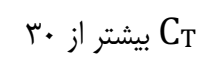

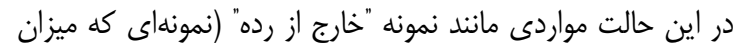

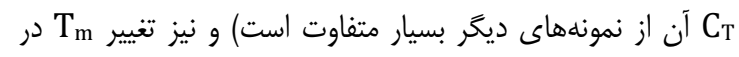

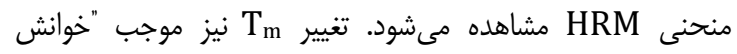

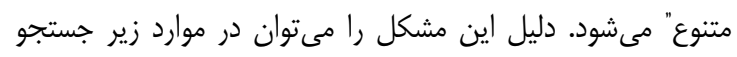

الف) حجم واكنش در مورد نمونه "خارج از رده" بهطور كاملاً

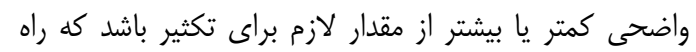

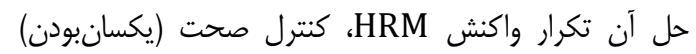
حجم نمونهها در خاهك هار، انجام اسيبين مختصر يِيش از بستن

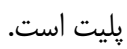

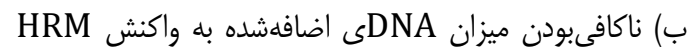

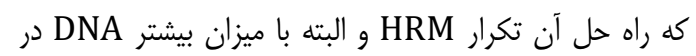

$$
\text { هر واكنش است. }
$$

ץ- بازدارندگى PCR: كمبردن است شيب منحنى تكثير و بيشتربودن

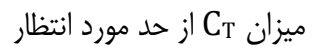

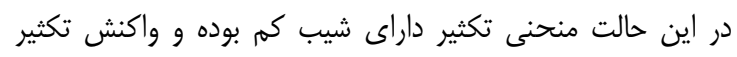

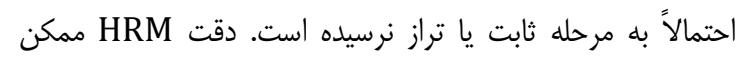

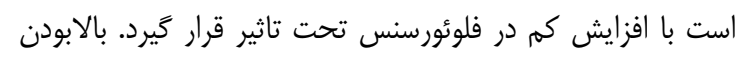

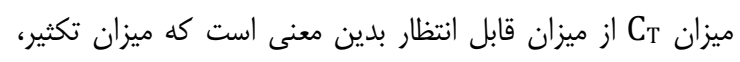

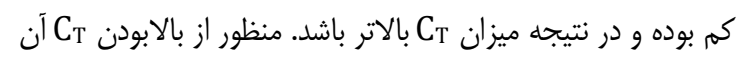

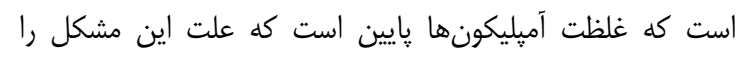
مىتوان موارد زير در نظر كرفت:
ه- كنترل فرآورده از بابت حضور نابجاى قطعهاى تكثيرشده

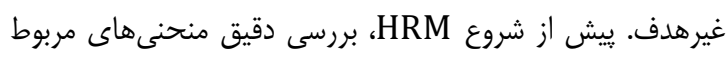

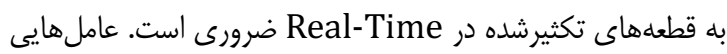

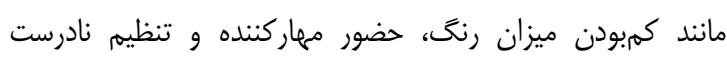

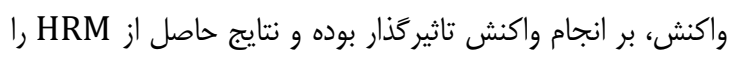
بعىارزش يا كمدقت مىنمايد [1, 2, 8, 11,

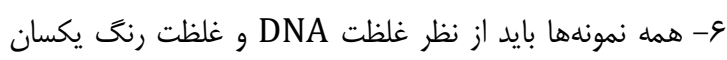

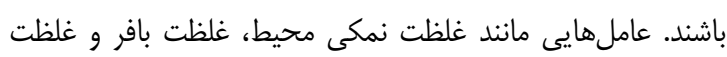

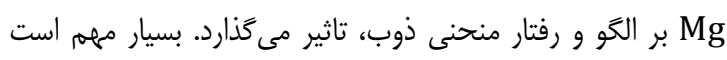

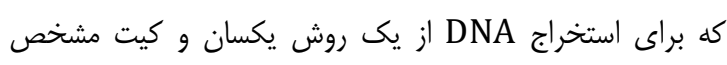
استفاده شود تا شرايط انجام واكنش در همه نمونهها يكسان باش يكاند

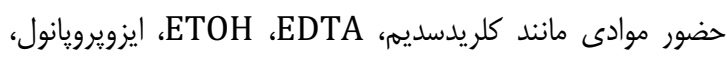
سديمسيترات و فنل موجب تغيير الخو و رفتار منحنى ذوب خواهد إنداند شد $[1,2,11,35$. V لولههايى كه واكنش در آنها انجام مىيابد بايد يكسان باشد،

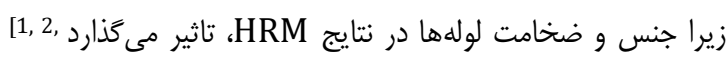
.11, 35] ^- نوع آنزيمى كه بهكار مىرود بهتر است از نوع "هاتاستارت"

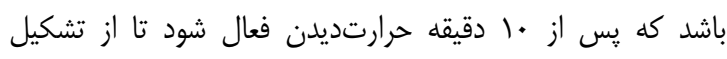

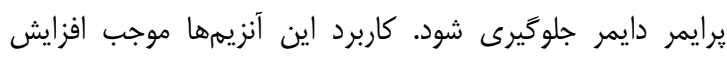
ويثگى و حساسيت واكنش نيز مى شود [1,

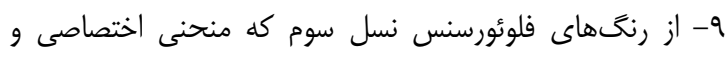

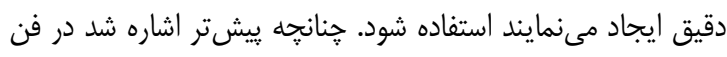

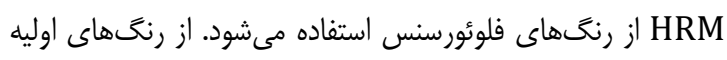

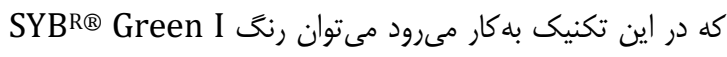

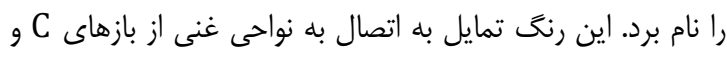

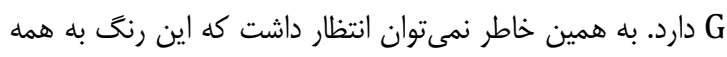

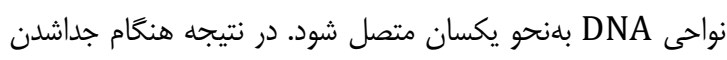

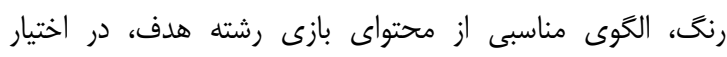

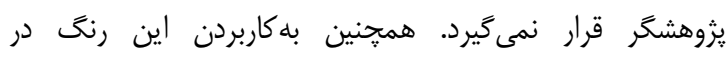

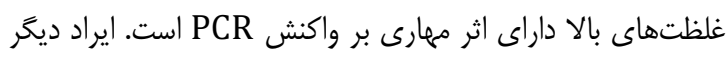

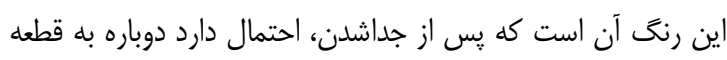
دورشتهاى DNA متصل شود [1, 2, 11, 28, 35, 40.

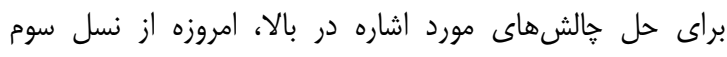

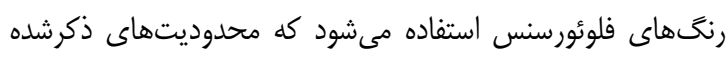

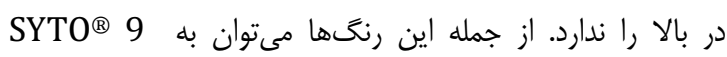
[1, 2, 11,35, Eva Green ،GreenLC Green

.40]

\section{عيب يابى واكنش HRM}

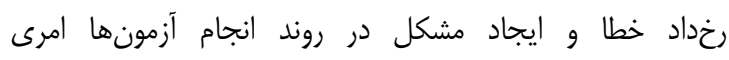

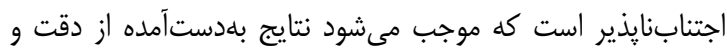


طراحى شود كه ناحيهاى كه تكثير مىشود تنها داراى يك بك جندشكلى باشد. ب) طول آمبليكون بيشتر از ميزان استاندارد است كه با طراحى إنى

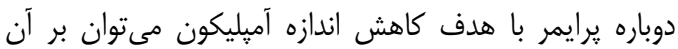
فايق آمد. צ- حضور بيش از سه خوانش متنوع:

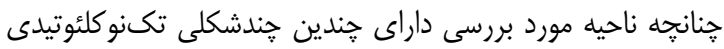

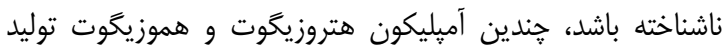

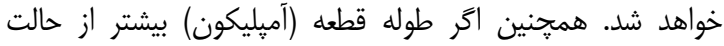

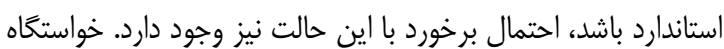
اين دشوارى را مىتوان به موارد زير نسبت داد:

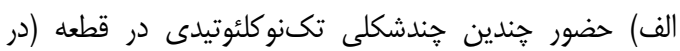
تعيين رنوتيب)، كه براى رفع آن توالىيابى فرآيند PCR برائل

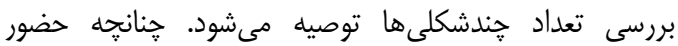

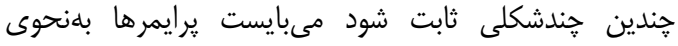

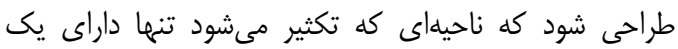

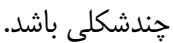
ب) طول آمبليكون بيشتر از ميزان استاندارد است كه مىتوان با إنا طراحى دوباره برايمر با هدف كاهش اندازه آمبليكون، به رفع إنعان

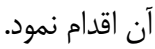

\section{نتيجلكيرى}

روشى بسيار قدرتمند، سريع، جامع و مفيد براى بهكاركيرى

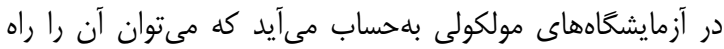
حلى ساده و سريع براى تعيين زنوتيڤ، رديابى جهش، تطابق توالى

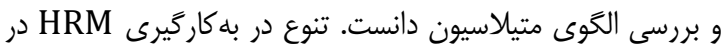

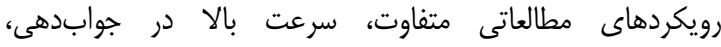

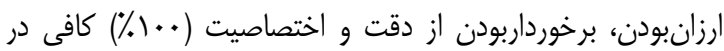

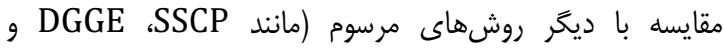

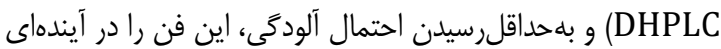

$$
\text { نه هندان دور جايكزين ساير فنون مشابه مى كند. }
$$

\section{تشكر و قدردانى: موردى توسط نويسندكان كزارش نشده است. \\ تاييديه اخلاقى: موردى توسط نويسندكان كزارش نشار نشده است.

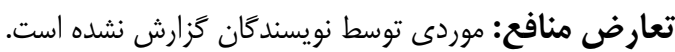

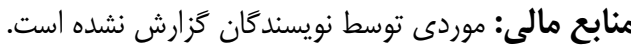

منابع

1- Erali M, Wittwer CT. High resolution melting analysis for gene scanning. Methods. 2010;50(4):250-61.

2- Erali M, Voelkerding KV, Wittwer CT. High resolution melting applications for clinical laboratory medicine. Exp Mol Pathol. 2008;85(1):50-8.

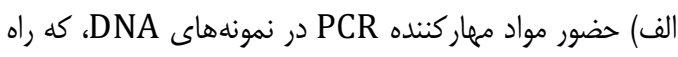

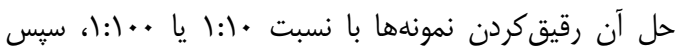
تكرار HRM است.

ب) غلظت نمكى نادرست كه براى رفع آن انجام تيتراسيون

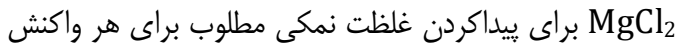
توصيه مى شود.

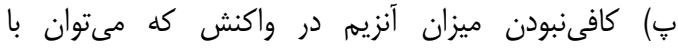

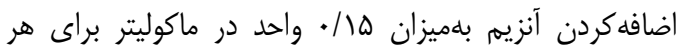

$$
\text { واكنش آن را مرتفع كرد. }
$$

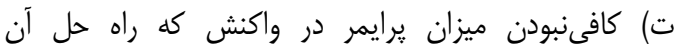

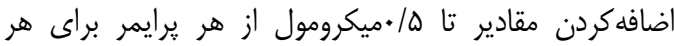
واكنش است. ث) بيشتربودن اندازه قطعهها از ..rاجفتباز كه با افزايش زمان كشيدگى (اكستنشن) در طول مرحله تكثير مىتوان با آن مقابله

$$
\text { كرد. }
$$

ج) اتصال يرايمرها به هندين توالى هدف و تكثير آنها كه با

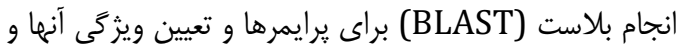

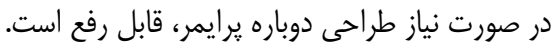

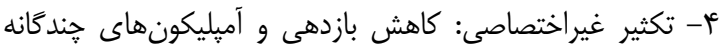

PCR در اين حالت بازدهى PCR كاهش مىيابد. افزون بر اين، حضور

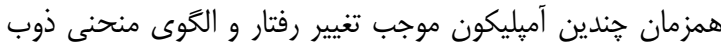

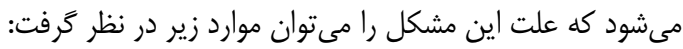
الف) غلظت نمكى نادرست كه راه حل آن آن انجام تيتراسيون براى ييداكردن غلظت مطلوب نمكى براى هر واكنش

ب) اتصال يرايمرها به جندين توالى هدف و تكثير آنها. براى رفع اين مشكل، انجام بلاست براى يرايمرها و و تعيين

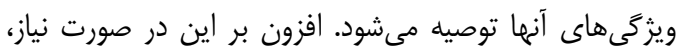

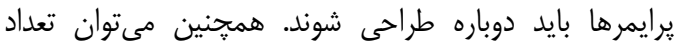

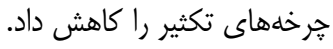

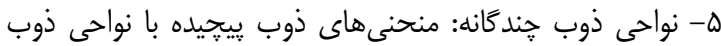
جندكانه شايان تاكيد است كه تفسير منحنىهاى ذوب يبيجيده با مناطق

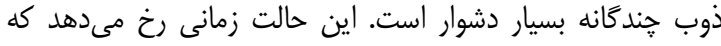

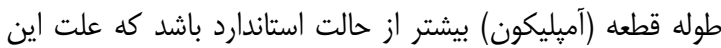
مشكل رامىتوان موارد زير در نظر كرفت:

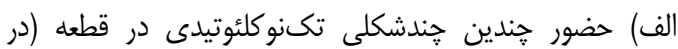

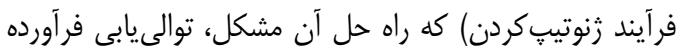

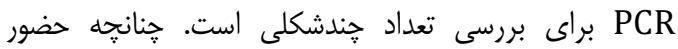

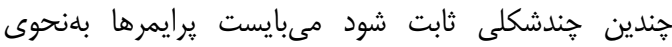




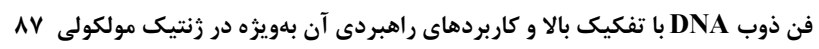

Science. Switzerland: Springer International Publishing; 2013. pp. 171-85.

20- Mann T, Humbert R, Dorschner M, Stamatoyannopoulos J, Noble WS. A thermodynamic approach to PCR primer design. Nucleic Acids Res. 2009;37(13):e95.

21- Chen D, Wang YY, Chuai ZR, Huang JF, Wang YX, Liu $\mathrm{K}$, et al. High-resolution melting analysis for accurate detection of BRAF mutations: a systematic review and meta-analysis. Sci Rep. 2014;4:4168.

22- Guedes JG, Veiga I, Rocha P, Pinto P, Pinto C, Pinheiro $\mathrm{M}$, et al. High resolution melting analysis of KRAS, BRAF and PIK3CA in KRAS exon 2 wild-type metastatic colorectal cancer. BMC Cancer. 2013;13:169.

23- Gonzalez-Bosquet J, Calcei J, Wei JS, Garcia-Closas M, Sherman ME, Hewitt S, et al. Detection of somatic mutations by high-resolution DNA melting (HRM) analysis in multiple cancers. PloS one. 2011;6(1):e14522. 24- Pichler M, Balic M, Stadelmeyer E, Ausch C, Wild M, Guelly C, et al. Evaluation of high-resolution melting analysis as a diagnostic tool to detect the BRAF V600E mutation in colorectal tumors. J Mol Diagn. 2009;11(2):140-7.

25- Do H, Krypuy M, Mitchell PL, Fox SB, Dobrovic A. High resolution melting analysis for rapid and sensitive EGFR and KRAS mutation detection in formalin fixed paraffin embedded biopsies. Bio Med Cancer. 2008;8:142.

26- Krypuy M, Newnham GM, Thomas DM, Conron M, Dobrovic A. High resolution melting analysis for the rapid and sensitive detection of mutations in clinical samples: KRAS codon 12 and 13 mutations in non-small cell lung cancer. Bio Med Cancer. 2006;6:295.

27- Liu Y-P, Wu H-Y, Yang X, Xu H-Q, Chen D, Huang Q, et al. Diagnostic accuracy of high resolution melting analysis for detection of KRAS mutations: a systematic review and meta-analysis. Sci Rep. 2014;4:7521.

28- Li J, Wang X, Dong R, Yang Y, Zhou J, Yu C, et al. Evaluation of High-Resolution Melting for Gene Mapping in Rice. Plant Mol Biol Rep. 2011;29(4):979-85.

29- Wittwer CT. High-Resolution Genotyping by Amplicon Melting Analysis Using LCGreen. Clin Chem. 2003;49(6 Pt 1):853-60.

30- Reed GH, Wittwer CT. Sensitivity and specificity of single-nucleotide polymorphism scanning by highresolution melting analysis. Clin Chem. 2004;50(10):1748-54.

31- Herrmann MG, Durtschi JD, Wittwer CT, Voelkerding KV. Expanded Instrument Comparison of Amplicon DNA Melting Analysis for Mutation Scanning and Genotyping. Clin Chem. 2007;53(8):1544-8.

32- Martino A, Mancuso T, Rossi AM. Application of highresolution melting to large-scale, high-throughput SNP genotyping: a comparison with the TaqMan method. J Biomol Screen. 2010;15(6):623-9.

33- Montgomery JL, Sanford LN, Wittwer CT. Highresolution DNA melting analysis in clinical research and diagnostics. Expert Rev Mol Diagn. 2010;10(2):219-40.

34- Janne PA, Borras AM, Kuang Y, Rogers AM, Joshi VA, Liyanage $H$, et al. A rapid and sensitive enzymatic method for epidermal growth factor receptor mutation screening. Clin Cancer Res. 2006;12(3 Pt 1):751-8.

35- Wojdacz TK. Methylation-sensitive high-resolution melting in the context of legislative requirements for validation of analytical procedures for diagnostic applications. Expert Rev Mol Diagn. 2012;12(1):39-47.
3- Applied Biosystems. A guide to High Resolution Melting (HRM) analysis. 2012. Available from: http://www.gene-quantification.com/ab-hrm-guide.pdf. 4- Ye MH, Chen JL, Zhao GP, ZHeng MQ, Wen J. Sensitivity and specificity of high-resolution melting analysis in screening unknown SNPsand genotyping a known mutation. Animal Sci Papers Reports. 2010;28(2):16170.

5- Cho MH, Ciulla D, Klanderman BJ, Raby BA, Silverman EK. High-resolution melting curve analysis of genomic and whole-genome amplified DNA. Clin Chem. 2008;54(12):2055-8.

6- Noori-Daloii MR. Medical molecular genetics in the third millennium. Tehran: Samber Publishing; 2009.

7- Castellanos E, Aranaz A, De Buck J. PCR amplification and high-resolution melting curve analysis as a rapid diagnostic method for genotyping members of the Mycobacterium avium-intracellulare complex. Clin Microbiol Infect. 2010;16(11):1658-62.

8- Reed GH, Kent JO, Wittwer CT. High-resolution DNA melting analysis for simple and efficient molecular diagnostics. Pharmacogenomics. 2007;8(6):597-608.

9- Watts AM. High resolution melt analysis: a novel method for studying the genetic relatedness of Pseudomonas aeruginosa isolates from clinical and environmental sources [Dissertation]. Brisbane, Australia: Queensland University of Technology; October 2013.

10- Noori-Daloii MR, Jalilian N. Applications of comparative genomic hybridization in cancer and genetic disorders: A review article. Tehran Uni Med J. 2011;68(1):1-11. [Persian]

11- QIAGEN. Principles of High Resolution Melting (HRM) technology [Cited 2015, 4 July]. Available from: https://www.qiagen.com/ir/resources/technologies/hr $\mathrm{m} /$ principle\%20of\%20hrm\%20technology/.

12- Noori-Daloii MR. Emery's elements of medical genetics. $6^{\text {th }}$ editon. Tehran: Jame'e Negar and Salami publishing; 2012.

13- Rubinstein WS. Hereditary breast cancer: pathobiology, clinical translation, and potential for targeted cancer therapeutics. Fam Cancer. 2008;7(1):83-9. 14- Noori-Daloii MR, Ebrahimzade Vesal E. Molecular genetics, diagnosis, prevention and gene therapy in prostate cancer: Review article. Tehran Uni Med J. 2009;67(1):1-14. [Persian]

15- Noori-Daloii MR, Maheronnaghsh R, Sayyah MK. Molecular genetics and gene therapy in esophageal cancer: A review article. Tehran Univ Med J. 2011:69(6):331-43. [Persian]

16- Wang F, Shen H, Guan M, Wang Y, Feng Y, Weng X, et al. High-resolution melting facilitates mutation screening of rpsL gene associated with streptomycin resistance in Mycobacterium tuberculosis. Microbiol Res. 2011;166(2):121-8.

17- Herrmann MG, Durtschi JD, Wittwer CT, Voelkerding KV. Expanded instrument comparison of amplicon DNA melting analysis for mutation scanning and genotyping. Clin Chem. 2007;53(8):1544-8.

18- Takano EA, Mitchell G, Fox SB, Dobrovic A. Rapid detection of carriers with BRCA1 and BRCA2 mutations using high resolution melting analysis. Bio Med cancer. 2008;8:59.

19- Batnyam N, Gantulga A, Oh S. An Efficient Classification for Single Nucleotide Polymorphism (SNP) Dataset. In: Lee R, editor. Computer and Information 
resolution DNA melting analysis for simultaneous mutation scanning and genotyping in solution. Clin Chem. 2005;51(10):1770-7.

39- Abd-Elsalam KA. Bioinformatics tools and guideline for PCR primer design. Afr J Biotechnol. 2003;2(5):91-95.

40- Kapa Biosystems. Introduction to high resolution melt analysis. Cape Town, South Africa: Kapa Biosystems Company; 2015. Available from: https://www.kapabiosystems.com/assets/Introduction to_High_Resolution_Melt_Analysis_Guide.pdf
36- Wojdacz TK, Dobrovic A. Methylation-sensitive high resolution melting (MS-HRM): A new approach for sensitive and high-throughput assessment of methylation. Nucleic Acids Res. 2007;35(6):e41.

37- Tse MY, Ashbury JE, Zwingerman N, King WD, Taylor SAM, Pang SC. A refined, rapid and reproducible high resolution melt (HRM)-based method suitable for quantification of global LINE-1 repetitive element methylation. BMC Res Notes. 2011;4:565.

38- Zhou L, Wang L, Palais R, Pryor R, Wittwer CT. High- 